\title{
How to build harmonious labor relations
}

\author{
LIU Yuxuan ${ }^{1, \text { a }}$ \\ ${ }^{1}$ Postgraduate of Public Management College of Tianjin University of Commerce \\ a1403602594@qq.com
}

Keywords: labor relationship; harmonious labor relationship; countermeasures .

Abstract. In recent years, the interest conflicts among subjects of labor relations have been gradually complicated. More and more contradictions have popped up in labor relations. Hidden labor disputes are increasing prominent, thus becoming an important factor threating sound and stable economic development and social harmony. This paper discusses about how to build harmonious labor relationship from four perspectives, namely governments, enterprises, labor unions and employees.

\section{Introduction}

Labor relations refer to social and economic relations formed among laborers, labor users and relevant organizations so as to realize the labor process. [ CHANG Kai. Labor Relations[M]. Beijing: China Labor Social Security Publishing House, 2005;4.] The essence of harmonious labor relations is to strike a balance between rights and obligations of two sides and to properly distribute interests. To build the basic framework of harmonious labor relations calls for government intervention, efforts of enterprises, mediation of labor unions and improvement of employees’ self-qualities.

\section{Government responsibilities}

Governments are public power representatives for employers and employees. They should comprehensively represent interests of both sides and alleviate labor disputes between them.

2.1 Constantly improve labor legislation and enhance publicity of relevant laws and regulations

As direct subjects in the labor relations system, governments standardize and guide the development of labor relations by formulating and carrying out labor policies. With the implementation of Labor Contract Law, Labor Dispute Mediation and Arbitration Law and Labor Contract Law Enforcement Regulations, the labor legal process has been constantly moving ahead. However, the promulgation of these laws and regulations is not a finishing point for labor legislation but a new starting point. First, during the law enforcement process, various channels should be utilized to publicize relevant laws and regulations to the whole society, and guide employers and employees to correctly understand the legal stipulations so as to better maintain their rights and interests and avoid influencing the law enforcement effects due to wrong interpretations. Second, it is necessary to speed up the formation and implementation of various laws consistent with the current legal system. Only this way can the legal system immediately respond to requirements of social development and labor relations changes, and solve new problems popping up in the new period and the new environment.

\subsection{Build a complete tri-party negotiation mechanism}

The tri-party coordination mechanism originates from Western market economies. It is an important mechanism for industrialized market economies to handle labor and capital affairs and relations. Currently, it has been an increasingly important method to coordinate labor relations under the current market economic conditions in China. The tri-party negotiation mechanism used to coordinate labor relations in China refers to the organization and operation system in which the government labor administrative department, the employer organization and the employee organization each choose a representative to coordinate labor relations according to certain systems, 
regulations and procedures. 1 The tri-party negotiation institution participates in mediation of major collective labor disputes, which can, on the one hand, effectively avoid further intensification of conflicts; on the other hand, form a complete and valid system which can respond to major and emergent disputes, improve the capability of the tri-party negotiation mechanism to deal with disputes and help intensify effectiveness of negotiation.

\section{Corporate responsibilities}

As the first line of defense against labor disputes, employers should realize the importance of building harmonious labor relations and pay attention to applications of various negotiation mechanisms within them so as to reduce the occurrence of labor disputes in terms of sources.

\subsection{Enhance publicity and training of labor laws and regulations within enterprises}

The implementation of labor laws and regulations is not only a responsibility of government, but also related to adjustment of corporate concepts and interest pattern under the new labor legal framework. An active law learning atmosphere should be formed among the administration level of enterprises. Legal qualities of relevant management personnel should be improved so as to prevent the occurrence of labor disputes. Besides, enterprises can train employees by holding lecturers, giving off labor laws and regulations manual or adopting other diversified ways. In this way, labor disputes caused by mistakes of employees ca be reduced and the awareness of employees to safeguard their legitimate rights and interests can be sharpened.

\subsection{Establish a complete internal corporate management system}

To further harmonize and stabilize labor relations can contribute to improvement of core competence of enterprises, maximization of enterprises' long-term interests and realization of their sustainable development. However, some enterprises might formulate regulations going against national and industrial regulations for their own interests. Such behaviors might seriously infringe on employees' legitimate rights and interests. By doing so, enterprises might be able to reap some profits within a short period of time. However, they put themselves in a risky situation, which might trigger major collective disputes.

A complete internal corporate management system should be a management system put in place in accordance with relevant laws and regulations, and reflecting practical situations and positive spiritual culture of enterprises. Under the management and guidance of a complete management system, behaviors of enterprises and employees can be standardized within the legal framework, and labor disputes can be efficiently curbed.

\subsection{Improve corporate human resources management level}

Prevention and reduction of labor disputes should be integrated in daily corporate management activities.

During the recruitment link, enterprises should strictly adhere to labor laws and regulations, and recruit based on the principle of fairness and justness so as to avoid labor disputes caused by employment discrimination. During the employment link, attention should be paid to conclusion and management of labor contracts and training agreements for the fear of possible disputes incurred during the personnel flow process. During the compensation management process, a compensation structure in line with characteristics of enterprises and accommodating to principles of fairness and efficiency should be designed. Then, during the operation process, salary delivery should be guaranteed to be in time so as to avoid labor disputes caused by delay of payment. Besides, qualities, knowledge of labor laws and dispute settlement skills of human resources management personnel

${ }^{1}$ CHENG Yanyuan. Labor Relations[M]. Beijing: China Renmin University Press, 2011: 283. 
should be improved so that dissatisfaction of employees can be solved within enterprises. In this way, costs of both sides ca be saved, and a solid foundation can be laid for the building of harmonious labor relations.

\section{Role of labor unions}

Labor unions represent interests and rights of employees. They play an important role in uniting employees, protecting their legitimate rights and interests and coordinating labor relations.

4.1 Give full play to the role of labor unions in protecting legitimate rights and interests of labor unions

During the building process of harmonious labor relations, labor unions can negotiate with employers so as to better protect legitimate rights and interests of employees. Labor unions should learn practical production and living situations of employees and inharmonious factors among labor relations. In this way, labor disputes can be nipped in the bud. Besides, labor unions should attach great importance to pushing ahead the formation of a collective contract system. The labor contract conclusion situations are not optimistic in private enterprises whose labor contract conclusion rate is low and labor disputes occur on a frequent basis. All these problems might seriously influence employees' legitimate rights and interests. In respond to these problems, labor unions should enhance their coordination efforts.

\subsection{Enhance the coordination role of labor unions}

Labor unions should enhance their independence and authoritativeness in the future so as to play a stronger role in coordinating labor relations and settling labor disputes. Apart from self-construction, labor unions can settle labor disputes within enterprises and nip them in the bud by supervising and building the mediation committee and other organizations within enterprises.

\section{Qualities of employees}

During the building process of harmonious relations, the enhancement of the subjective role of employees and the improvement of their comprehensive qualities are essential to coordinated and stable development of labor relations.

\subsection{Improvement of employees' skills}

In the current labor market, the labor supply exceeds demand. Employees should improve their own skills so as to get an edge in the fierce competition instead of being employees with a high substitutability. If employees increase their competiveness in the employment market, the situation of "strong capital and weak labor" 2 can be alleviated. Besides, improvement of employees' labor skills is positive to increase corporate profits. Therefore, enterprises should encourage employees to improve their labor skills. Only when enterprises and employees achieve a win-win pattern can harmonious labor relations be possibly built.

\subsection{Improvement of employees’ legal qualities}

The development and changes of labor relations is a mutual game process between employers and employees. Working skills and comprehensive qualities of employers directly decide their position in the game. Under the socialist market economic conditions and during the socialist legalization process, it is all the more necessary to enhance legal learning and training of employees so that employees can resort to legal weapons to safeguard their own legitimate rights and interests. At the

\footnotetext{
2.PENG Teng. On the strong capital and weak labor of the current stage in China[J]. Journal of Lanzhou Commercial College, 2009, (6): 27-33.
} 
same time, they can avoid going against labor laws and regulations due to lack of adequate legal knowledge.

\section{Conclusions}

With the rapid development of China's economy, harmony and stability of labor relations are faced with huge challenges. As interest differentiation and conflicts between employers and employees become increasingly prominent, building harmonious labor relations is of vital importance.

Harmonious labor relations are a triple-win pattern among enterprises, employees and governments. The author is convinced that, through joint efforts of the three parties, harmony of labor relations can be realized at an earlier date.

\section{References}

[1] Wu H. How to Build Harmonious Labor Relations of Socialist on the Basis of Marxist Labor Theory[C]. 2007.

[2] Zhu C H. How to Build the Harmonious Labor Relations for Construction Companies[J]. Value Engineering, 2015.

[3] Wang L. How to build a harmonious labor relations in the private sector[J]. Journal of Yichun College, 2011.

[4] Wang L. How to build a harmonious labor relations in the private sector[J]. Journal of Yichun College, 2011.

[5] P.G. Clem, M. Rodriguez, J.A. Voigt and C.S. Ashley, U.S. Patent 6,231,666. (2001)

[6] Ding Y Y, Wu J Y. Discussion on how to build harmonious industrial relation in Chinese Non-State-Owned enterprises[J]. Science Research Management, 2005. 